MATEC Web of Conferences 53, 01004 (2016)

DOI: $10.1051 /$ matecconf/20165301004

(C) Owned by the authors, published by EDP Sciences, 2016

\title{
Chemical properties of reinforcing fiberglass in aggressive media
}

\author{
Arina Avdeeva ${ }^{1, a}$, Inga Shlykova ${ }^{1}$, Maikel Perez ${ }^{1}$, Maria Antonova $^{1}$ and Svetlana Belyaeva ${ }^{1}$ \\ ${ }^{1}$ St.Petersburg State Polytechnical University, 195251, St.Petersburg, Russian Federation
}

\begin{abstract}
In this article describe reinforced fiberglass. Fiberglass - fiber or complex yarn, formed from glass. The main application area of fiberglass and fiberglass textile materials is their use as reinforcing elements of fiberglass plastics and composites. For its consideration, conducted laboratory tests were conducted. As a result of the research was chosen the best of the characteristics of fiberglass.
\end{abstract}

\section{Introduction}

The modern level of technological development has led to the creation of new materials, with special properties not inherent in the natural materials [1-3]. Such new synthetic materials includes glass fibre (fiberglass) [4]. Fiberglass has valuable properties: incombustibility, resistance to corrosion and bio effects, sufficiently high strength and relatively low density in combination with excellent optical, electrical, heat and sound insulation properties [5, 6]. It is increasingly used in various industries [79]. Industrial production of continuous fiberglass in the Soviet Union, was first organized in 1942.

Fiberglass is used in the production of insulating materials, which ensures reliable protection for people and equipment during prolonged exposure to high temperatures (long-term up to $700{ }^{\circ} \mathrm{C}$, shortterm up to $900^{\circ} \mathrm{C}$ ) and protection from vibration for its entire lifetime [10,11]. The strength of the fiberglass reinforcement is not inferior to steel reinforcement, however due to its higher cost, it is mainly used in critical structures which demand special requirements [12]. The basic design principles of reinforced concrete structures are applicable to concrete elements with fiberglass $[13,14]$

\section{Materials and Methods}

Fiberglass is a fiber or yarn, formed from glass. In this form, the glass demonstrates unusual properties: it will not crack and not break, and is instead easy to bend without breaking $[15,16]$.

Fiberglass is made in three different types:

- Reinforced fiberglass - consists of polymer compounds, reinforced with fiberglass, which can be made in different types, depending on the needed composition and on the qualities of tasks performed;

- Fiberglass reinforced plastic - consists of a plastic materials, reinforced by glass;

\footnotetext{
${ }^{a}$ Corresponding author : arina.avdeeva@rambler.ru
} 
- Carbon plastic or carbon fiber-reinforced polymer. This is the most expensive form of all the available types of fiberglass, and yet it is also the most durable and the lightweight.

This article will examine reinforced fiberglass and will carry out experiments to identify the best among several samples.

Selecting the right type of fiberglass (composite) is important to ensure a long service life and to reduce the risk of fracture of parts made from fiberglass plastics [17-20].

If the wrong type of fiberglass is selected, corrosive substances may come into contact with the fiberglass. This can lead to deterioration of the characteristics of the fiberglass, can cause a disruption in the bond with the resin, and lead to a reduction in structural properties [21].

A part or construction made of fiberglass-plastics can consist of materials in the form of fabric, roving, mat and veil. Roving is a bundle of glass fibers which is spliced from several glass strands. Roving can be straight or assembled. Straight roving provides the durability of parts and structures made of fiberglass-plastics. Assembled roving can be chopped. It replaces mats of chopped fiberglass and is used in the processes of impregnation by spraying for forming laminates, which are put to work in corrosive environments. The mat is made from chopped fibers or continuous fibers. The former provides strength if overlapping layers manually. The latter provides lateral resistance, high mechanical properties, and resistance to corrosion. The veil is used for forming the layer that follows the mat. It serves for the protection of fiberglass-plastic against an aggressive chemical environment.

Veils can be non-woven veils or surface veils. Non-woven veils enhance the strength of the corrosion barrier and also provide a bond with the layered material. Surface veils isolate the internal fibers from abrasion and corrosion. To ensure the highest level of corrosion resistance, it is important to specify the type of veil, independent of the specification of the mat. In Figure 1, it shows an example of structures of (FRP), including the corrosion barrier and the structural element.

When using reinforcement from fiberglass materials, you must specify the desired type of fiberglass for the structural element and the corrosion barrier.

Filament winding or laminate

(example: pipes, tanks, ductwork, etc.)

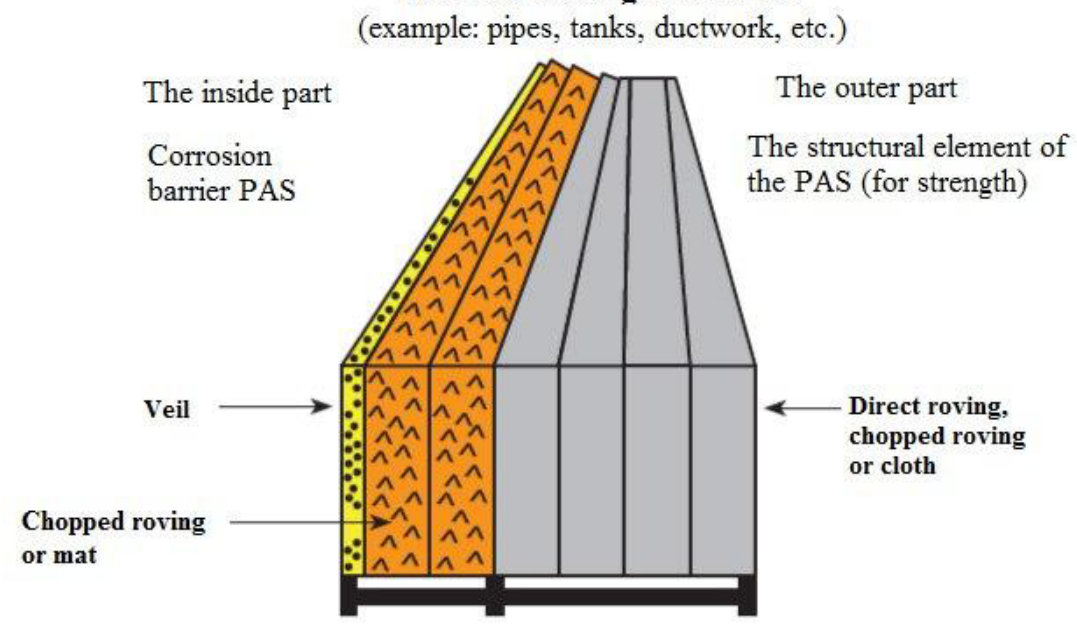

Figure 1. The winding of fibers or layered material.

Most of the products from fiberglass-plastic for applications in corrosive environments (pipelines, tanks, ducts, chimneys) are manufactured using the processes of winding the fibers and pultrusion and contains from $60 \%$ to $70 \%$ reinforcing fiberglass by weight.

Pultrusion is the process for producing profiles by continuous extrusion through a heated shaping nozzle of reinforcing glass materials impregnated with a thermosetting resin. [22, 23]

For fibre production, the raw materials used are those which are used in glass technology. [24, 25] The fiberglass is determined by composition and properties of glass from which it is made. Depending on its composition there are several brands of such glass (table 1). 
Table 1. Typical composition of fiber-glass, $\%$ by weight.

\begin{tabular}{|c|c|c|c|c|c|}
\hline \multirow{2}{*}{$\begin{array}{c}\text { Glass } \\
\text { component }\end{array}$} & \multicolumn{5}{|c|}{ Glass mark } \\
\cline { 2 - 5 } & $\mathrm{A}$ & $\mathrm{C}$ & $\mathrm{E}$ & $\mathrm{S}$ \\
& $\begin{array}{c}\text { Strongly } \\
\text { alkaline }\end{array}$ & $\begin{array}{c}\text { Chemikal- } \\
\text { resistant }\end{array}$ & Elektroinsulated & Extra-strong & \\
\hline $\mathrm{SiO}_{2}$ & 70.5 & 64 & 53 & 64.2 & 99.95 \\
\hline $\mathrm{Al}_{2} \mathrm{O}_{3}$ & 3.1 & 5.5 & 15 & 24.8 & - \\
\hline $\mathrm{Fe}_{2} \mathrm{O}_{3}$ & 0.2 & 1 & 0.1 & 0.21 & - \\
\hline $\mathrm{CaO}$ & 8.7 & 12 & 17 & 0.01 & - \\
\hline $\mathrm{MgO}$ & 3.1 & 2 & 4 & 10.27 & - \\
\hline $\mathrm{Na}_{2} \mathrm{O}$ & 12 & 9.5 & 0.3 & 0.27 & - \\
\hline $\mathrm{B}_{2} \mathrm{O}_{3}$ & - & 2 & 10 & 0.01 & - \\
\hline $\mathrm{BaO}$ & - & 2 & - & 0.2 & - \\
\hline Other & 2.4 & 2 & 0.6 & 0.03 & 0.05 \\
\hline
\end{tabular}

A-glass is also called calcosodic, C-glass is called sodium borosilicate, E-glass is called aluminosilicate, and S-glass is called magnesia-alumina-silica. A number of application areas, such as the oil and gas industry, power plants, mining industry, heavy industry, water, sewage, marine work, tidal energy, wave energy and other areas require during construction the use of the best performance materials. The purpose of the research was the selection of the best characteristics of fiberglass along with samples.

\section{Results and Discussion}

Together with the Owens Corning Company a laboratory study of four samples were carried out. The tested glass types were the following: E-glass, C-glass, glass Advantex ${ }^{\circledR}$, and AR-glass.

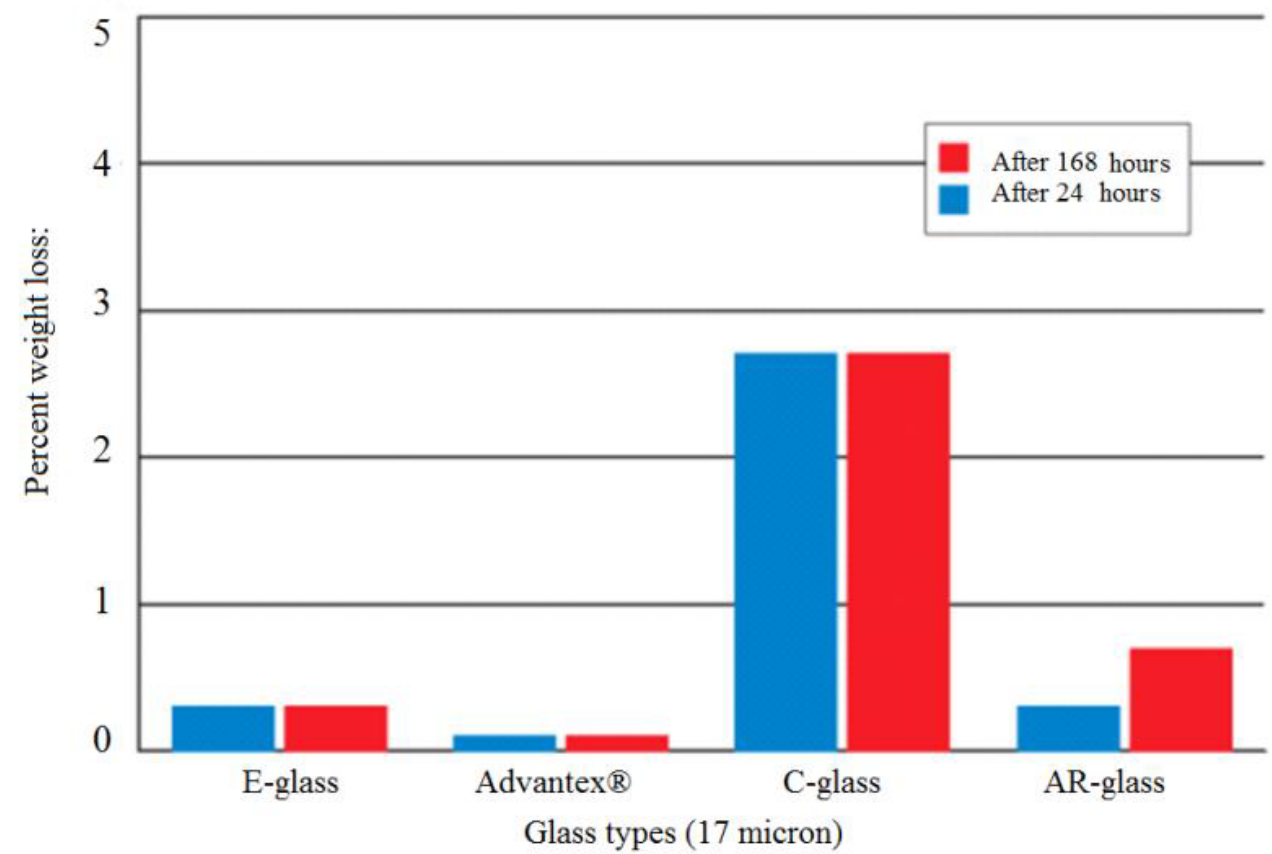

Figure 2. Tests results of the $80 \%$ acetic acid at $50^{\circ} \mathrm{C}$. 


\section{MATEC Web of Conferences}

Table 2 presents the main properties of the selected samples.

Table 2. Properties of glass-reinforced plastics

\begin{tabular}{|c|c|c|}
\hline Glass & Main properties & Durability \\
\hline E-glass & electrotechnical & middle \\
\hline C-glass & corrosion resistance & low \\
\hline glass Advantex ${ }^{\circledR}$ & corrosion resistance & middle \\
\hline AR-glass & alkali resistance & low \\
\hline
\end{tabular}

Results for ammonium hydroxide (high $\mathrm{pH}$ ) show little effect on the glass Advantex ${ }^{\circledR}$. C-glass received significantly more damage than other types of fiberglass. Veil of C-glass is not the best choice as a corrosion barrier element.

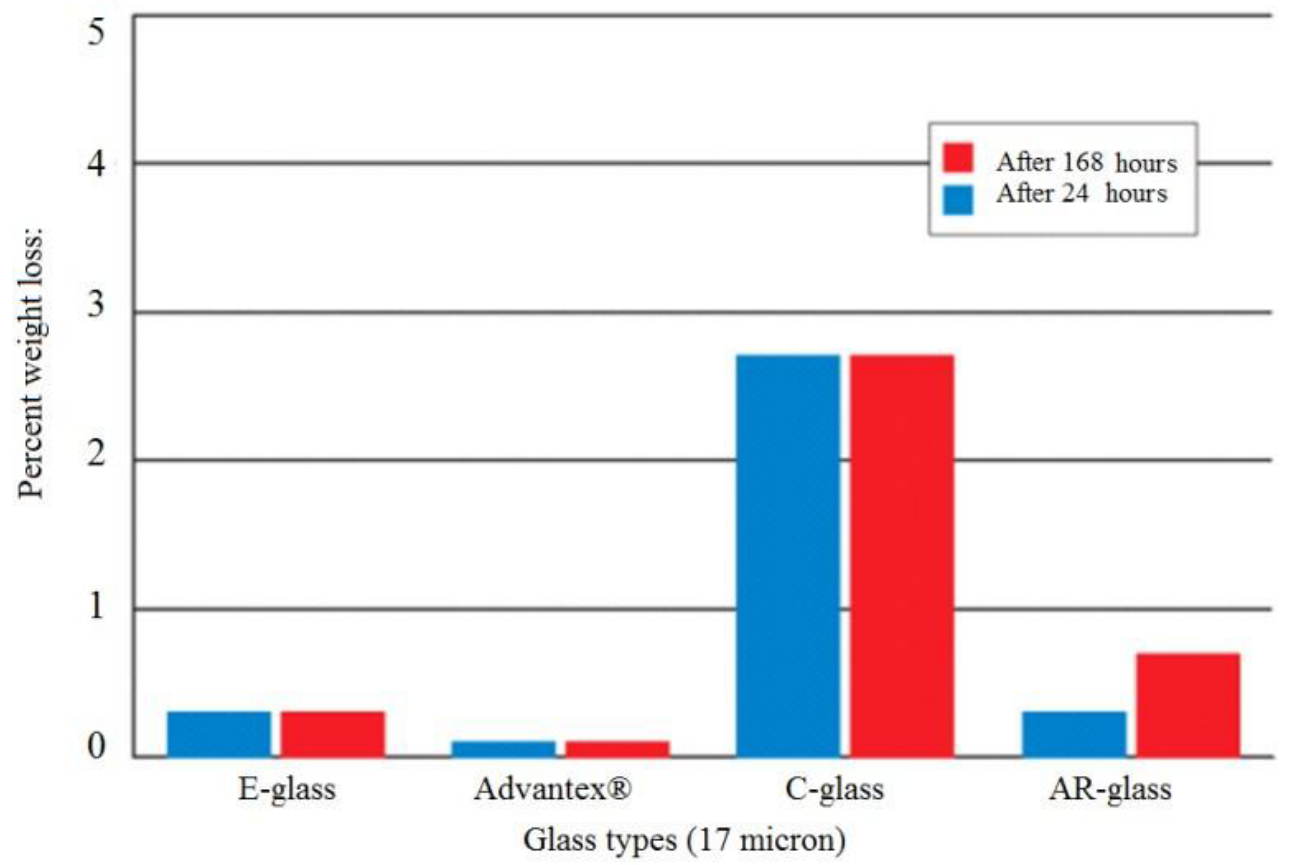

Figure 3. Tests results of the $28 \%$ ammonium hydroxide at $30^{\circ} \mathrm{C}$.

Aqua regia is a mix of hydrochloric and nitric acids. It is a strong acid. The use of E-glass is not recommended due to the high percentage of weight loss. Veil of C-glass is also not the best choice. 


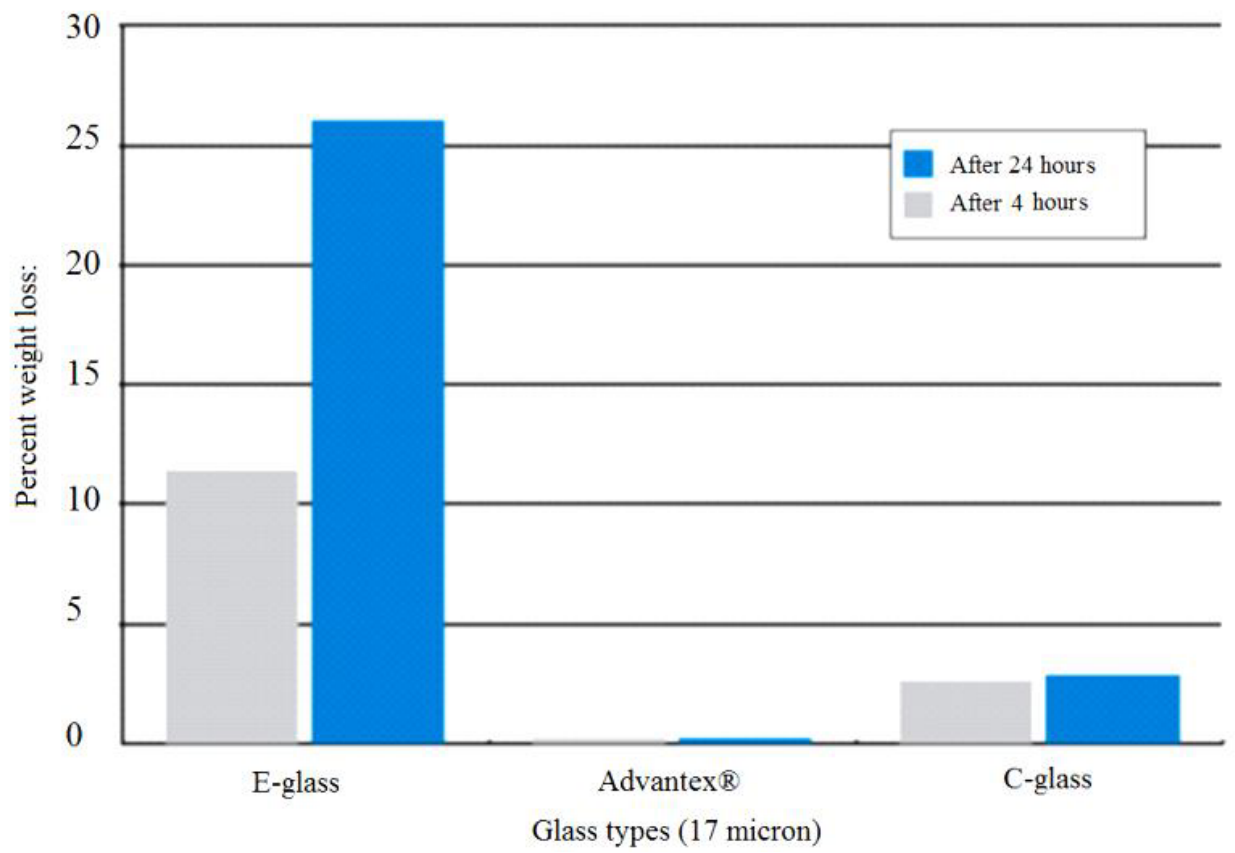

Figure 4. Tests results of the $5 \%$ aqua regia at $30^{\circ} \mathrm{C}$.

Citric acid is unique. It forms a chelate (complex) with defined elements, etched from fiberglass. Fiberglass Advantex ${ }^{\circledR}$ does not contain so many elements preferred by citric acid, as do E-glass or Cglass. Other studies (R. L. Jones, University of Curtin, Australia) showed that several other organic acids, cause corrosion of the glass in a similar way.

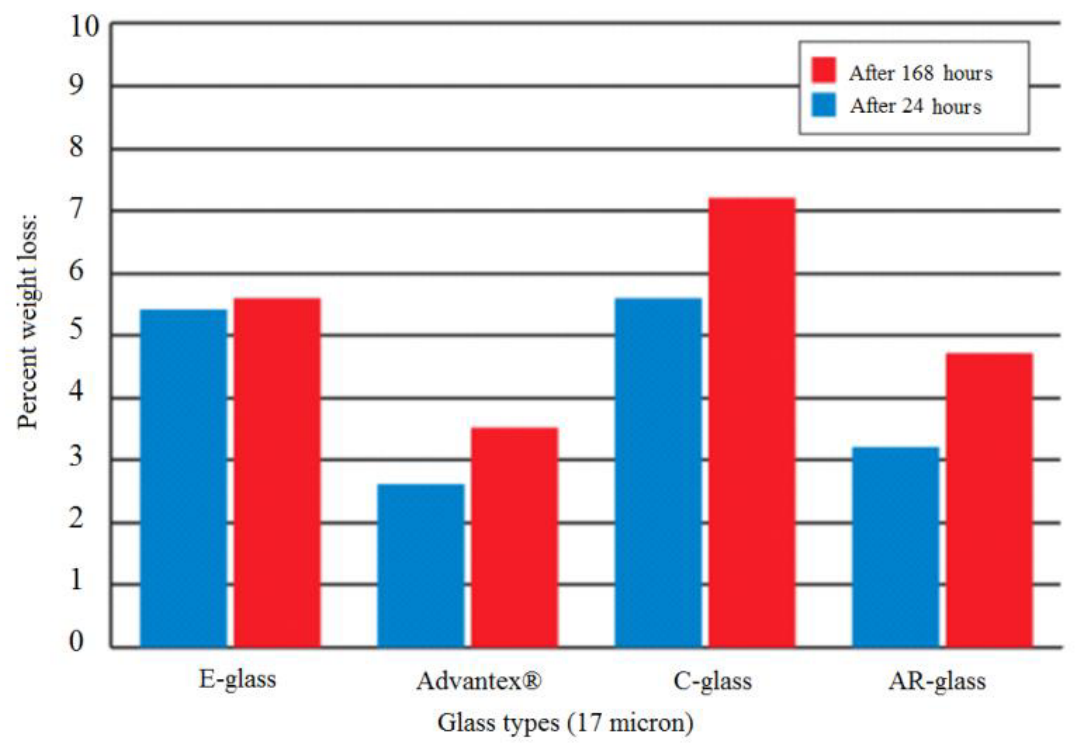

Figure 5. Tests results of the $50 \%$ citric acid at $96^{\circ} \mathrm{C}$.

Long-term testing of composite cores for durability in terms of corrosion show that the glass Advantex ${ }^{\circledR}$ in deionized water at $25^{\circ} \mathrm{C}$ has a higher durability than E-glass. Glass Advantex ${ }^{\circledR}$ after 50 
years retains $41.0 \%$ of its original strength. E-glass is able to withstand the same load for only 100 hours.

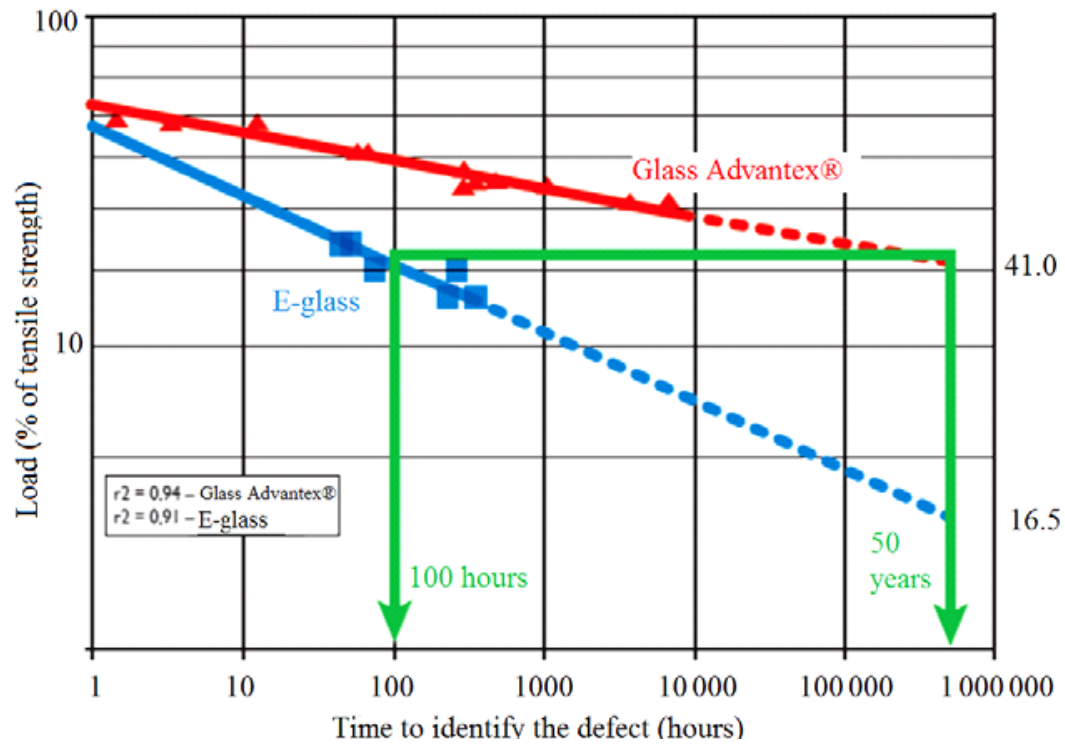

Figure 6. Tests results of the fracture properties under load, the composite rods in deionized water.

The difference between the glass Advantex ${ }^{\circledR}$ and E-glass is not reflected in the results of the measurement of weight loss of pure glass. Measurements of weight loss in deionized water do not identify differences to the same extent as the more expensive tests for durability in terms of corrosion. However, measurements of weight loss indicate that the veil of C-glass is a bad choice for a corrosion barrier.

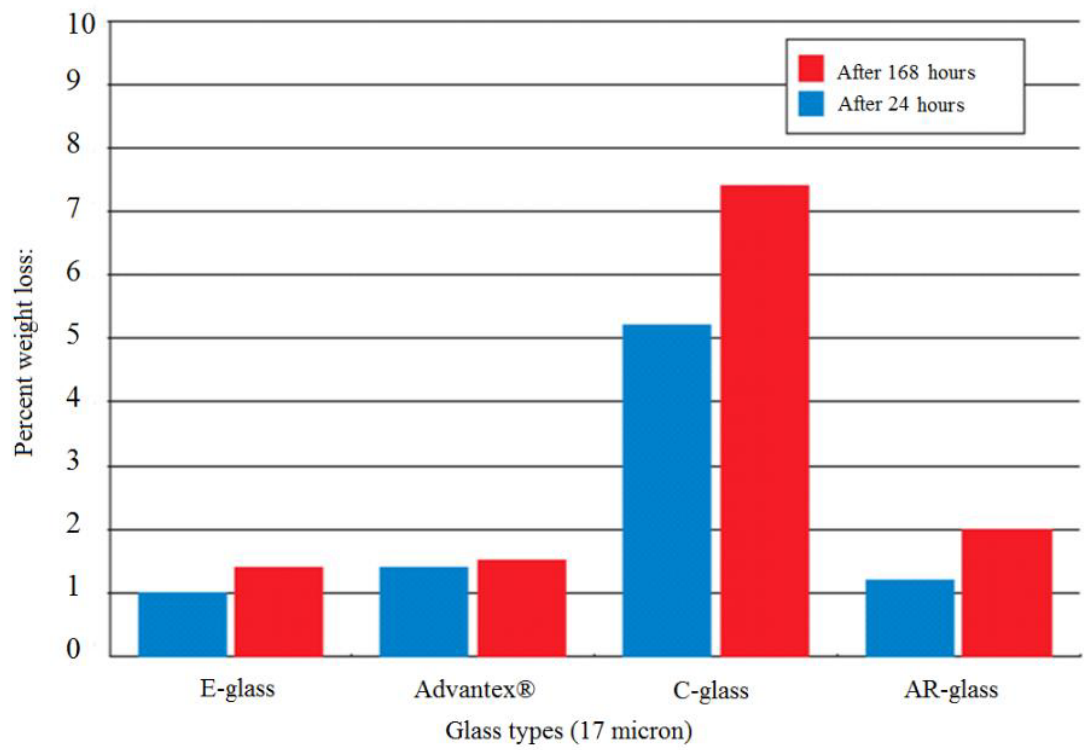

Figure 7. Tests results of the deionized water at $96^{\circ} \mathrm{C}$. 
E-glass is not recommended for any structural member that comes in contact with ferric chloride. AR-glass does not possess sufficient mechanical properties for a structural element in a fiberglassplastic construction.

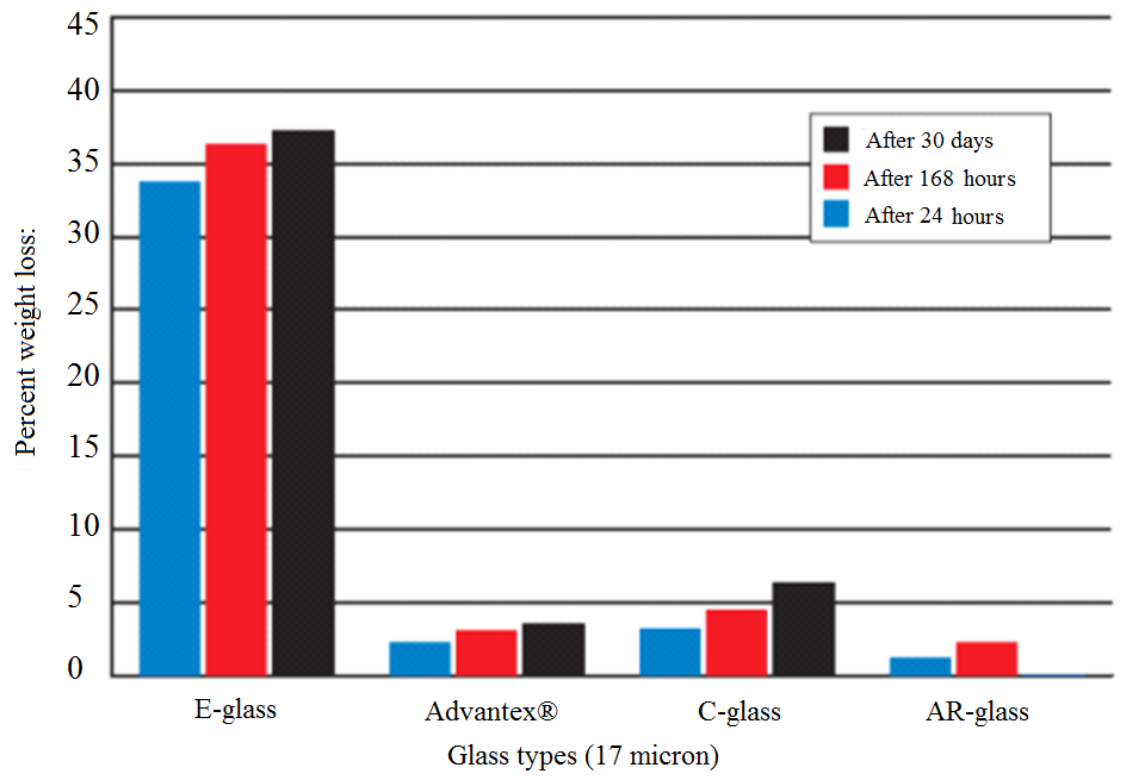

Figure 8. Tests results of the $40 \%$ ferric chloride at $96^{\circ} \mathrm{C}$.

Analysis of the results of tests for durability under conditions of corrosion shows that the composite rods with E-glass loses strength with considerably faster speed than composite rods with the glass Advantex ${ }^{\circledR}$. After 50 years, composite rods with glass Advantex ${ }^{\circledR}$ are still able to withstand $12.1 \%$ of the original load, while the composite rods with E-glass can withstand this load only for 73 hours. Etching of the glass fiber of E-glass leads to the formation of a porous outer surface and to subsequent spiraled cracking. The glass Advantex ${ }^{\circledR}$ remains intact.

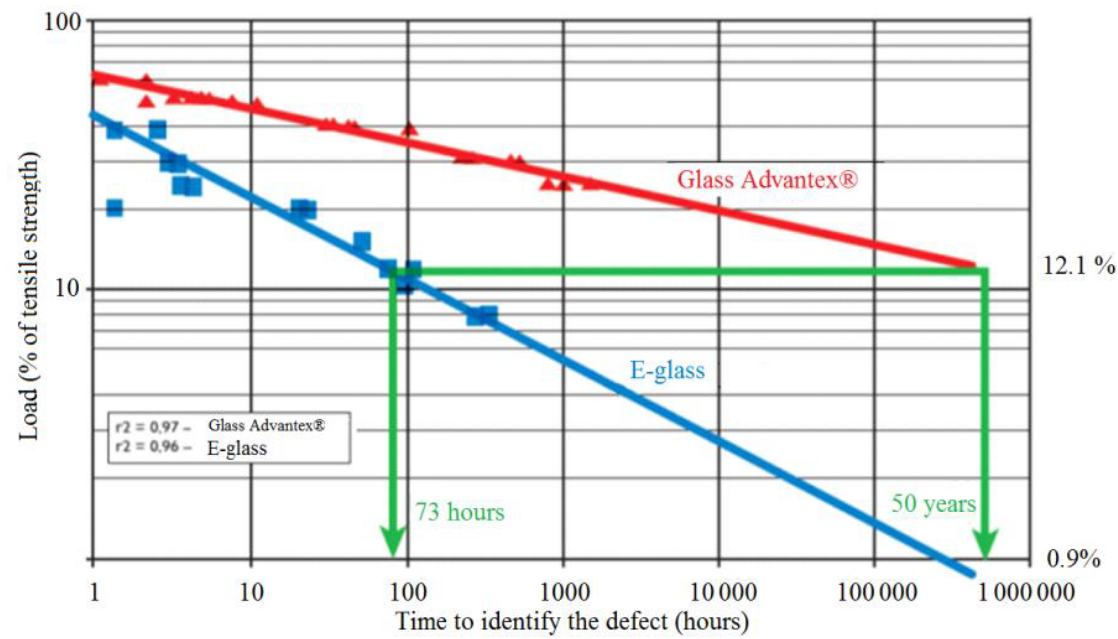

Figure 9. Tests results of the composite layered material under the influence of solution of acids $\left(\mathrm{HCl}-\mathrm{H}_{2} \mathrm{SO}_{4}\right)$. 


\section{MATEC Web of Conferences}

Long-term strength tests in terms of corrosion show that the glass Advantex ${ }^{\circledR}$ has the advantage over E-glass in the sea. The test results show that after 50 years of immersion in seawater, a composite rod with fiber glass Advantex ${ }^{\circledR}$ can withstand $43.1 \%$ of the ultimate load, while the composite rods with E-glass can withstand this load only for 75 days.

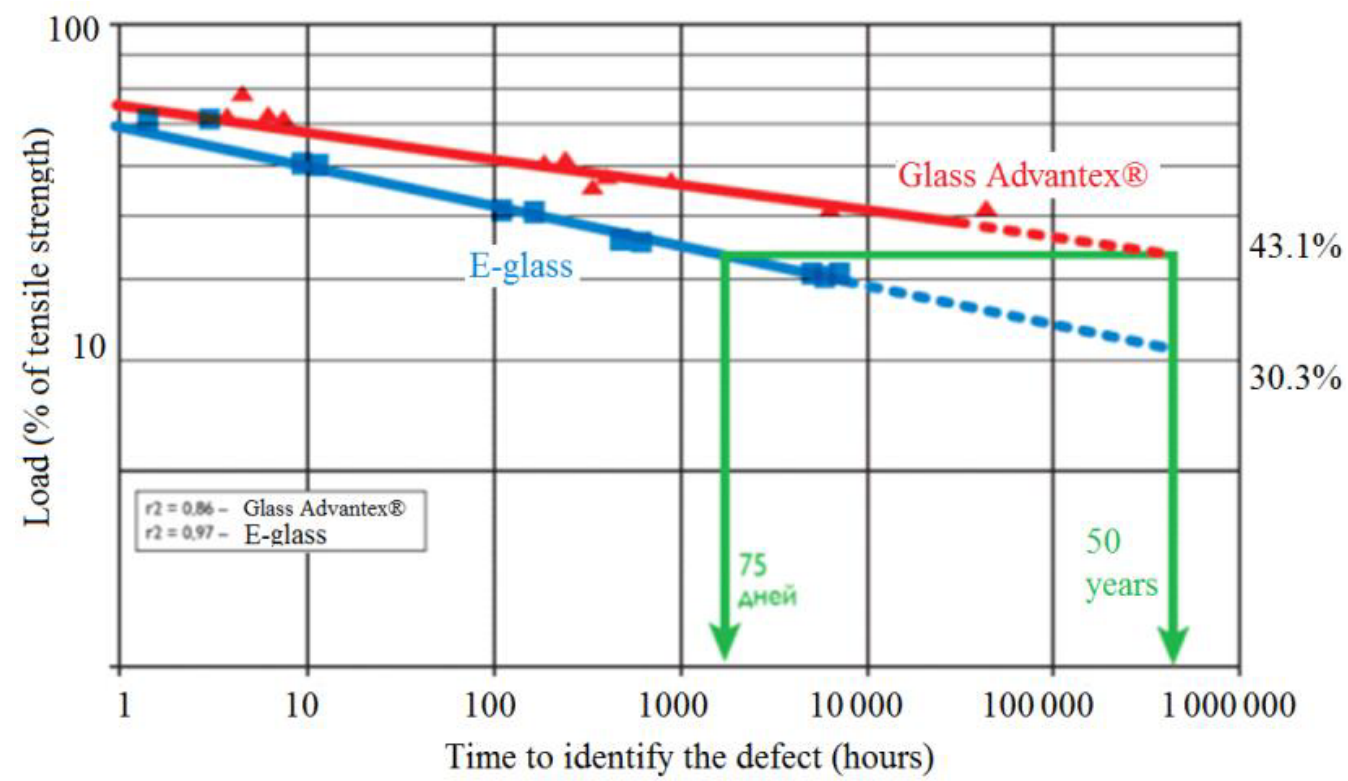

Figure 10. Tests results of the tear strength of the composite rods under loading in $5 \%$ hydrochloric solution.

Short-term weight loss measurements do not reflect an important difference in the characteristics between E-glass and Advantex glass ${ }^{\circledR}$. Nevertheless, they clearly show that the veil of C-glass is a poor choice for use in seawater.

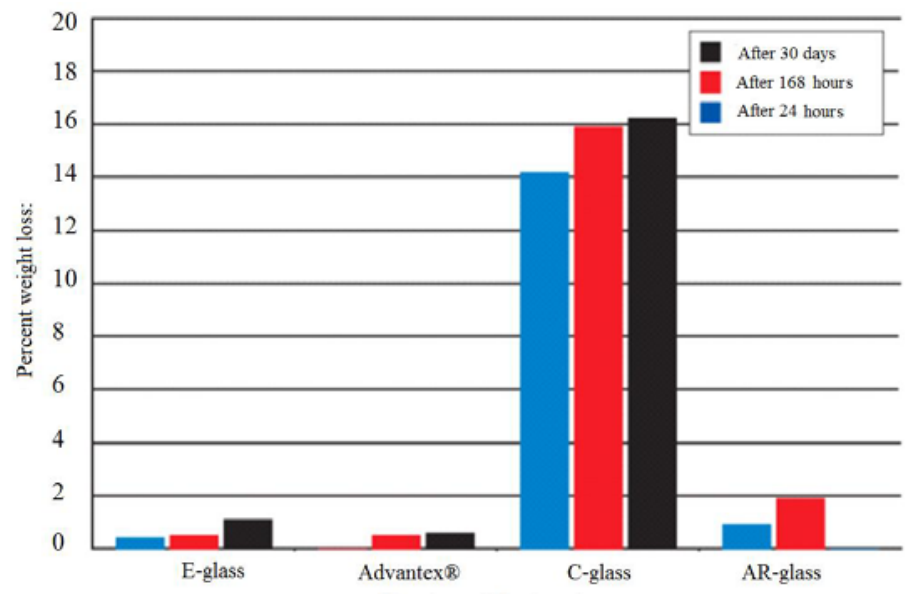

Figure 11. Tests results of the $10 \%$ sodium chloride at $96^{\circ} \mathrm{C}$. 


\section{Conclusion}

Acetic acid to some extent affects fiberglass, and to a greater extent C-glass. Ammonium hydroxide severely damaged C-glass, and had a negligible impact on the glass Advantex®. In aqua regia, E glass was shown to prove the worst. In citric acid, all the samples behaved about the same with medium damage. Under load in deionized water, E-glass is less durable than Advantex ${ }^{\circledR}$. In ferric chloride, AR-glass had a lower weight loss, but this glass is only available for specific fields of use. Under load in hydrochloric acid, E-glass loses strength much earlier Advantex ${ }^{\circledR}$ glass. In sea water, C-glass is the worst result in comparison with E-glass and Advantex ${ }^{\circledR}$.

The results obtained with glass having the highest rates in all environments, is Advantex ${ }^{\circledR}$.

Glass Advantex ${ }^{\circledR}$ can be recommended for use as a structural element and for the mat in corrosion barrier composition. Also C-glass can be considered for use as a veil for the inner surface of a corrosion barrier.

\section{References}

1. R.V. Lesovik, S.V. Klyuyev, Magazine of Civil Engineering, 3, 41-98 (2012)

2. Dzh. Lyubin, Handbook of composites (Metallurgy, Moscow, 1988)

3. R. Kamnik, B. Kovačič, B. Pribicević, A. Đapo, Geodetski List, 69 (3), 171-188 (2015)

4. N.K. Tsirlin, Continuous inorganic fibers for composite materials (Metallurgy, Moscow,1992)

5. A. Abbasi, P.J. Hogg, Temperature and environmental effects on glass fibre rebar: modulus, strength and interfacial bond strength with concrete (Engineering, Moscow, 2005)

6. A.R. Gizdatullin, V.G. Khozin, A.N. Kuklin, A.M. Khusnutdinov, Magazine of Civil Engineering, 3, 40-50 (2014)

7. S.V Klyuyev, Magazine of Civil Engineering, 8, 61-103 (2012)

8. Dzh. Piatti, Advances in composite materials, (Metallurgy, Moscow,1982)

9. O.N. Stolyarov, A.S. Gorshkov, Magazine of Civil Engineering, 4, 21-25 (2009)

10. N.Yu. Makusheva, N.B. Kolosova, Construction of Unique Buildings and Structures, 10 (25), 60-72 (2014)

11. T.S. Morozov, V.D. Kuznetsov, Magazine of Civil Engineering, 3, 35-38 (2010)

12. B.A. Muralidhar, Materials and Design, 52, 835-840 (2013)

13. Z.S. Teplova, S.S. Kiski, D.V. Nemova, A.V. Sokolov, Construction of Unique Buildings and Structures, 4 (19), 62-74 (2014)

14. Interstate standard GOST 31938-2011 "Reinforcing composite polymer for the reinforcement of concrete structures. General specifications"

15. Dzh Uiktn, E. Skal, Fiber composite materials, (Metallurgy, Moscow, 1978)

16. B. Kovačič, R. Kamnik, A. Štrukelj, N. Vatin, Procedia Engineering, 117 (1), 800-806 (2015)

17. Glass Fiber Reinforcement Chemical Resistance Guide (Metallurgy, Moscow, 2011)

18. S.A. Elders, A.A. Sundukova, Strengthening masonry composite materials and screw rods (State Technical University, Moscow, 2011)

19. J. Frank, Reinforced plastics composites (Univ of Sheffield, London, 1992)

20. M. Grosse, R. Hartnack, S. Lehmann, K. Rautenstrauch, Modelling of timber-concrete composites connected only at a few discrete points (Bauhaus-Universität Weimar, Berlin, 1992)

21. B. Kovačič, R. Kamnik, M. Premrov, Survey Review, 43 (320), 150-161 (2011)

22. Y. Barabanshchikov, S. Belyaeva, A. Avdeeva, M. Perez, Applied Mechanchanics and Materials, 475-481 (2015)

23. P.I. Silin, Development of technology for concrete samples, using a modified polymer reinforcement (State Technical University, Moscow, 2010)

24. Z.-Q. Ying, C.-B. Du, Y.-Y. Wang, Numerical simulation of particle reinforced composite using extended finite element method Fourth Harbor Engineering Institute Co (Bauhaus-Universität Weimar, Berlin, 1992) 